\title{
Rehabilitating Salt-Desert Ecosystems Following Wildfire And Wind Erosion
}

\section{Over a decade of research shows revegetation success in the Utah desert.}

\author{
By Robert L. Newhall, Thomas A. Monaco, W. Howard Horton, \\ R. Deane Harrison, and Richard J. Page
}

$\mathrm{O}$ ver the last century and a half, the salt desert shrub ecosystem of the Great Basin has changed to include many new invasive annual weeds. Cheatgrass is the most prevalent. This introduced annual weed brings a faster re-occurring fire-cycle to the landscape. On average, it is estimated that cheatgrass ecosystems in the western United States burn every seven years. Records indicate that native vegetation evolved under less frequent fire events. Consequently, vegetation composition of many areas in Utah and Nevada has changed to reflect the impacts of cheatgrass and wildfire.

In early 1982 abnormally high amounts of precipitation in Utah began what was to be the beginning of three years of record-breaking winter snowpacks. High precipitation generally increases the production of vegetation in the spring and facilitates large buildups of fine-fuels when cheatgrass dries in the summer heat. The Great Basin is also known for its prolonged droughts, some lasting several decades or longer. Together, high fine-fuel loads and drought create a situation for potential wildfire in Utah.

\section{The Wildfire \& Blowout}

On July 4, 1986, a lightning strike started a wildfire on the Twin Peaks BLM Allotment, 10 miles west of Kanosh, Millard County, Utah. Plant composition at the time of burning was $80 \%$ annual weedy species (cheatgrass, halogeton, and annual mustards), the other $20 \%$ consisted of shadscale, four-winged saltbush, green molly, and bottlebrush squirreltail. The wildfire burned over 18,000 acres of public, state, and private lands.
Officials at Bureau of Land Management (BLM), Warm Spring Resource Area, commented to local residents that 'the wildfire burned an area which virtually sterilized the soil.' The following fall, the BLM in consultation with permittees, re-seeded most of the burned areas with crested wheatgrass, prostrate kochia, winterfat, and four-winged saltbush using a standard rangeland drill. These seeded areas were higher in elevation, hence, they had more potential precipitation, and exhibited fair

Sidebar Table. Species mentioned in this article.

Common name

Scientific name

'Hycrest' crested wheatgrass

'Ephraim' crested wheatgrass

'Alkar' tall wheatgrass

'P-27' Siberian wheatgrass

'Arriba' western wheatgrass

'Luna' pubescent wheatgrass

'Critana' thickspike wheatgrass

Syn-A Russian wildrye

'Bozoisky' Russian wildrye

'Volga' mammoth wildrye

'Prairieland' Altai wildrye

'Nezpar' Indian ricegrass

Mountain ryegrass

'Immigrant' prostrate kochia

'Hatch' winterfat

Four-winged saltbush

Shadscale

Green molly

Bottlebrush squirreltail

Common cereal rye

Halogeton

Cheatgrass
Agropyrum cristatum $\mathrm{x}$

A. desertorum

Agropyrum cristatum

Thinopyrum ponticum

Agropyron fragile

Pascopyrum smithii

Thinopyrum intermedium

Elymus lancelaotus

Psathyrostachys juncea

Psathyrostachys juncea

Leymus racemosus

Leymus angustus

Achnatherum hymenoides

Secale mountanum

Kochia prostrata

Karascheninnikovia lanata

Atriplex canescens

Atriplex confertifolia

Kochia americana

Elymus elymoides

Secale cereale

Halogeton glomeratus

Bromus tectorum 


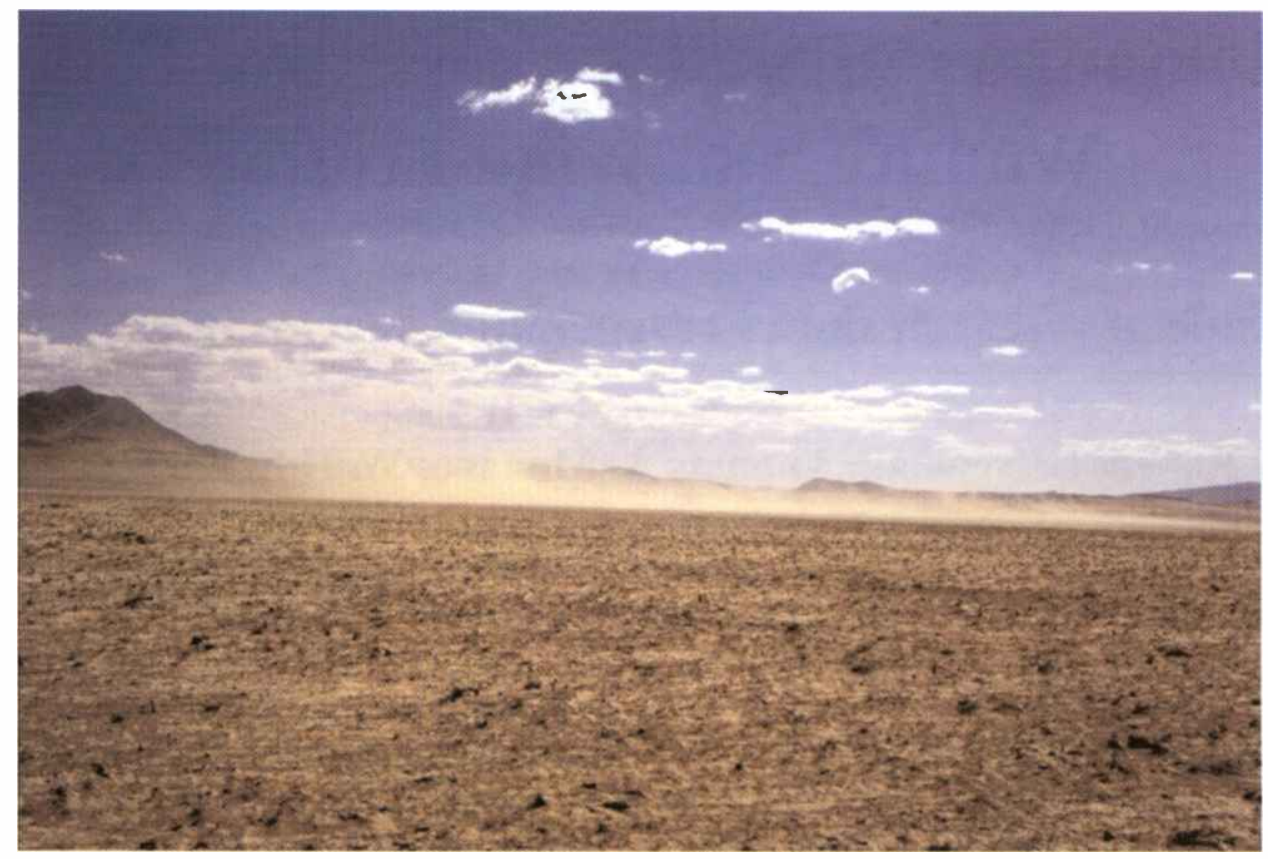

Figure 1. Dust storm at Clearspot in 1987.

stands of perennial vegetation. In lower elevation areas, the seeding provided little in the way of newly established vegetation to compete with encroaching annual vegetation.

Approximately 640 acres in the middle of the burned area was not re-seeded due to high wind erosion events occurring almost daily. This unseeded area had experienced severe wind erosion damage, referred to as a "blowout." The blowout was accentuated by a regional drought in the summer of 1986 . This blowout area is downwind of two parallel mountain ranges. The strong southwesterly winds accelerate between them and bear down on this area producing avalanching soil erosion and dust clouds, consisting of fine silt and clay (Figure 1).

Farmers in Delta, 40 miles north of the site, reported alfalfa crops covered with dust. A concerned member of the District Grazing Advisory Board commented that hay harvested from fields was sold for $20 \%$ less than normal because of dust contamination. Travelers along Interstate- 15 reported what appeared to be more wildfires at the site, but what they saw were really dust clouds. Residents of Provo, a community 120 miles to the north, reported seeing the dust clouds. After 18 months, the affected area had experienced a loss of 3 to 8 inches of topsoil (500 to 1300 tons/acre) (Figure 2).

\section{A Cooperative Effort}

Experts from the BLM, Forest Service, Agricultural Research Service (ARS), Soil Conservation Service (now NRCS), and Utah State University Cooperative Extension Service met to assess the problem and discuss methods to stabilize and rehabilitate this damaged area. The cooperative team decided to minimize future wind erosion by strategically placing straw bales to form windbreaks, and by planting common cereal rye in the spring of 1987.

However, by November of the same year, cereal rye plants had been sheared off by blowing soil, and native seed sources for natural reclamation were likely blown away as well. Airborne dust continued to be visible over the area most of the time. Drifting soil accumulated on roads and filled in low ground depressions. Three local watering reservoirs were also being filled with moving soil. The blowout continued to produce clouds of soil that moved northward during the summer of 1988 .

The cooperative team recognized that soil loss could limit rehabilitation options. Consequently, an action plan began to take shape in addressing possible remedies to prevent further resource degradation in this arid ecosystem. A pre-treatment BLM assessment taken in 1987 indicated that rehabilitation potential would be greatly diminished if action 


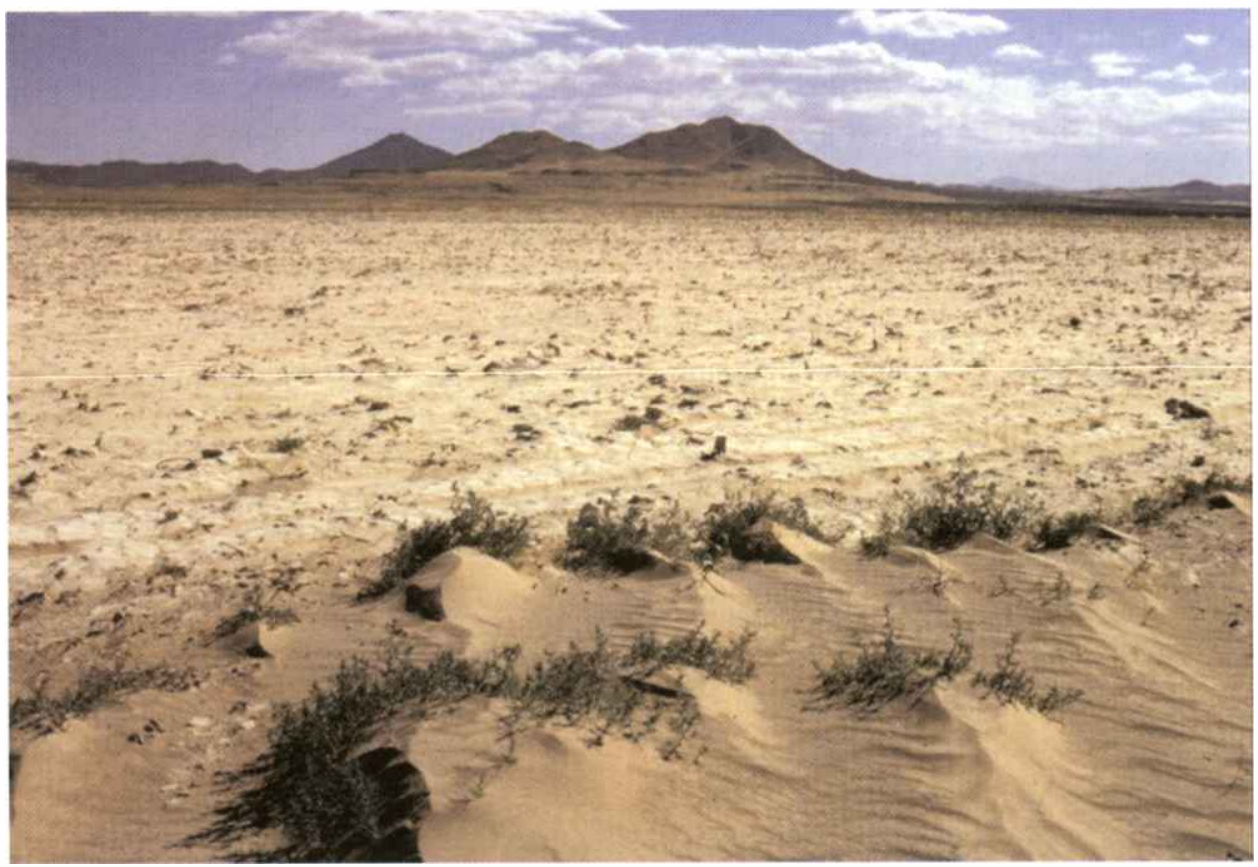

Figure 2. Clearspot blowout in 1988.

was not taken to stabilize the soil (Table 1). The rehabilitation effort addressed three concerns: the continued irreversible loss of soil, loss of livestock and wildlife forage, and the likelihood of cheatgrass and halogeton invasion.

Table 1. 1987 BLM pre-treatment impact assessment.

\begin{tabular}{lcc}
\hline \hline & Without Treatment & With Treatment \\
\hline Livestock AUMs & 1179 & 4070 \\
Wildlife AM & 44 & 213 \\
Soil Erosion (cu/yd/sq mile) & 1600 & 325 \\
\hline
\end{tabular}

The cooperative team selected a 20 -acre test site in the center of the blowout. The experimental design included seeding plants perpendicular to the prevailing winds, and comparing three conservation tillage drills and a standard rangeland drill. Part of the site was fertilized with 45 pounds of nitrogen per acre. Treatments included, straw mulch $(4,000$ pounds/acre of barley straw), soil berms (12 inches in height and 8 to 10 feet apart), crested wheatgrass straw bales for reduction of wind speed, and polyacrylamide drilled with the seed for surface water retention and to assist in seedling establishment. Twenty-four different plant species (including a number of cultivars of some species) were chosen which had demonstrated potential success in other salt desert shrublands in Utah (see sidebar table).

The site consisted of a deep silt loam soil to a depth of 8 feet. Even with the loss of the top 8 inches of soil, the team felt confident about using these species. Plant materials were drill seeded December 6,1988 . Each species was seeded in plots that were 1,400 feet long and 8 to 12 feet wide. Drills were equipped with press wheels and depth bands to insure seed/soil contact and seed placement between 0.25 to 0.50 inches deep. The rangeland drill did not penetrate more than 0.50 inches in depth because the soil surface was frozen. All perennial grasses were seeded at 10 to 12 pounds pure live seed per acre. 'Hatch' winterfat was drill seeded at 5 pounds per acre and 'Immigrant' prostrate kochia at 3 pounds pure live seed per acre. Plot evaluations for species establishment were conducted on April 5, 1989, April 24, 1991 and October 2, 2002.

\section{Establishment Results}

In 1989 the fertilizer and polyacrylamide applications did not appear to make a difference on stand establishment of seeded species. 'Immigrant' prostrate kochia had the highest establishment, which appeared to increase when straw bales were used to reduce wind erosion. Pelleted and regular 'Hatch' winterfat seed had comparable establishment. 'Montana' ryegrass was absent in 1989 , and failed 
to recruit in subsequent years. The conservation tillage drills and the rangeland drill produced comparable plant establishment. 'Hycrest' crested wheatgrass establishment was 30 percent greater in the barley straw mulch treatment than when seeded alone. The modified John Deere Flexi-Planter produced the most consistent and highest establishment of perennial grasses. 'Hycrest' crested wheatgrass also had the highest perennial grass establishment followed by 'Bozoisky' Russian wildrye, 'Syn-A' Russian wildrye, 'Prairieland' Altai wildrye, and 'Luna' pubescent wheatgrass.

In 1991, results showed polyacrylamide and drilling type had few effects on plant establishment. However, unlike the 1989 evaluation, straw bales and barley straw mulch did not improve establishment. Soil berms appeared to still have a positive effect on plant establishment. Percent cover of all perennial grasses decreased between 1989 and 1991. Existing perennial grass cover in 1991 was primarily 'Hycrest' crested wheatgrass, 'Syn-A' Russian wildrye, 'Bozoisky' Russian wildrye, and 'Ephriam' crested wheatgrass. 'Hatch' winterfat had increased cover in both pelleted and standard seed drilling treatments between 1989 and 1991 . Soil stabilization increased within the plots by 1991.

Outside the experimental area, annual weed invasion by cheatgrass and halogeton did occur, and temporally stabilized soils and decreased airborne dust. In general, perennial plant cover increased adjacent to the soil berms, where increased snow retention and wind protection likely enhanced seedling survival.

\section{Stability Restored}

A site evaluation in 2002, 14 years after rehabilitation efforts, revealed new information about longterm site stability. Drought conditions persisted continuously during this time frame. Average annual precipitation for the area is 7.35 inches per year, with most occurring as winter snowfall. Records for this 14-year period indicate an average of 5.54 inches per year.

Natural recruitment of the native species, shadscale, green molly, and bottlebrush squirreltail, slightly increased in all plots except for those seeded with 'Hycrest' crested wheatgrass (Figure 3). 'Immigrant' prostrate kochia and 'Ephraim' crested wheatgrass (a rhizomatous cultivar) had the highest percent cover of any seeded species. 'Hatch' winterfat increased in percent ground cover even when growing with 'Immigrant' prostrate kochia.

The area outside the 20 acre test site, which was not reseeded at all after the fire, was dominated by cheatgrass and halogeton. The success of this endeavor is even brighter when one considers that the blowout area was only protected from livestock grazing for the first 2 winters following seeding; however, subsequent years allowed for winter grazing of cattle.

The years following rehabilitation efforts included the most intense regional drought in recent history. In spite of these unfavorable environmental conditions, perennials plants established at the blowout site and deterred wildfire and wind erosion. This evaluation indicated that rehabilitation efforts should utilize perennial plants materials that rapidly establish and persist.
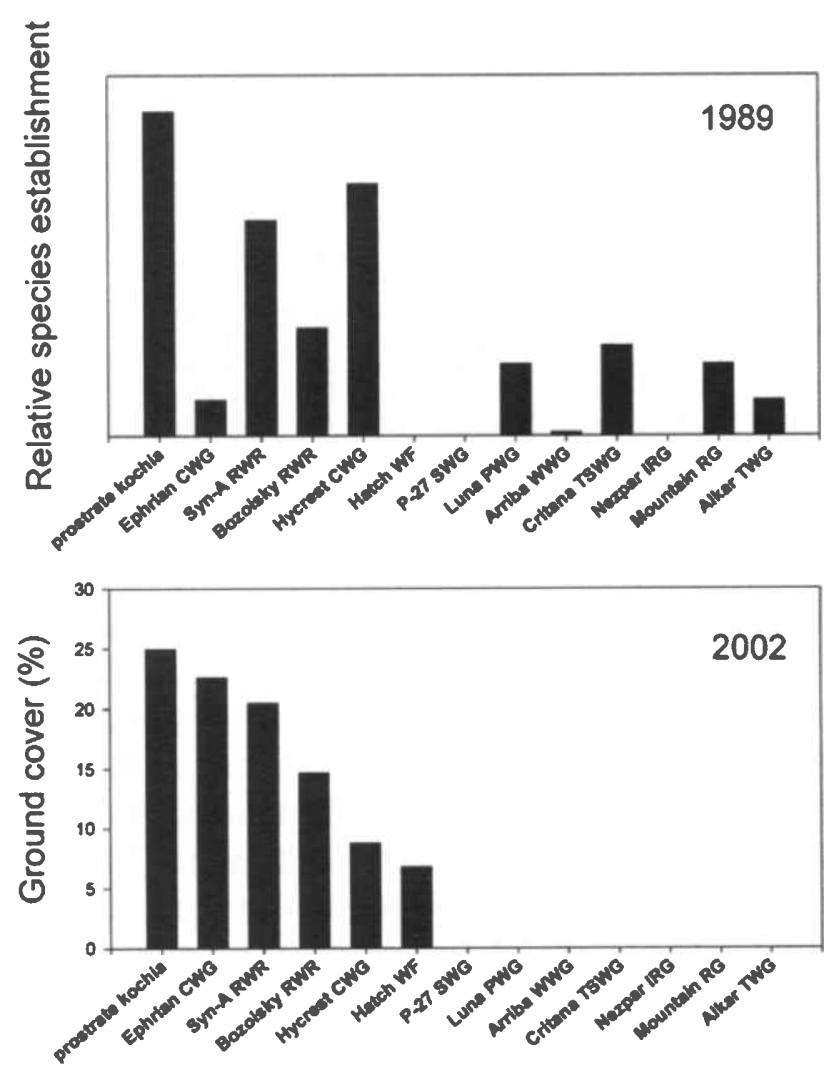

Planted species

Figure 3. Plant species evaluation in 1989 and 2002. 


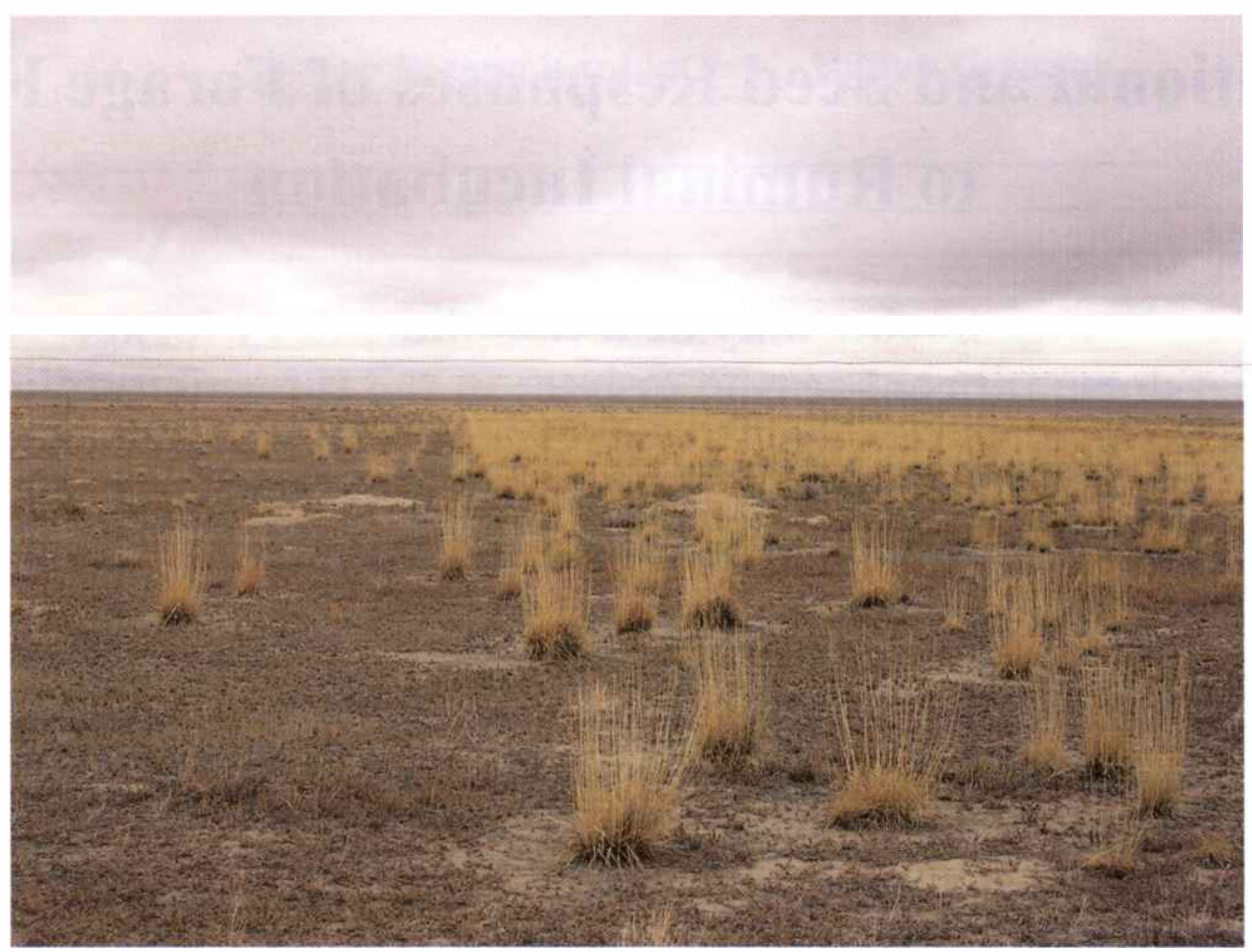

Figure 4. Border of experimental area in Fall 2002.

Our results also suggest that, only the drought tolerant introduced species that have evolved for centuries under livestock grazing, persisted at this site (Figure 4). The seeded native species did not persist. In contrast, 6 of the introduced species persisted during the 14-year period. If the introduced species had not been included in the reclamation effort, the site may not have been stabilized and cheatgrass likely would have invaded the test area. The persistent species may also aid in stabilizing similar ecological range sites with rehabilitation needs.

We anticipate that if wildfire does not occur in the next decade, the experimental site will undergo future increases in perennial plant cover and become more stable. The use of introduced species appears to be a viable management opportunity to rapidly stabilize damaged areas, and possibly provide an ecological bridge to re-establish native species.

Over time, the cost to continually contend with wildfire, restoration efforts, reduced livestock/wildlife grazing, added regulations, etc. adds up to substantial expenditures of the citizen's tax dollars. The process of changing the vegetative landscape to a more sustainable and stable system may or may not have higher initial costs than fire fighting and suppression. However, when planned and conducted successfully, stabilization of these damaged areas will provide economical and social benefits for generations to come.

Acknowledgements: The authors graciously recognize the assistance of BLM field staff, Tom Simper (USDA-NRCS), Justin Williams (ARS), R. Goodey (Utah State University), and J. C. Gibbs (NRCS, Retired) for assistance with data collection.

About the Authors: Robert Newhall is an Extension Specialist, College of Agriculture, Utah State University, Logan, UT 84322-4820; Thomas Monaco and W. Howard Horton are Ecologist and Range Scientist, respectively, at the USDA-ARS Forage and Range Research Laboratory, Utah State University, Logan, UT 84322-6300; R. Deane Harrison is a Range Scientist, Utah State University, Logan, UT and Richard Page is a State Watershed Specialist USDI-BLM (Retired). Corresponding author is Robert Newhall. Contact him via email: bobn@ext.usu.edu.

\section{References}

Page, R.J., P. Rasmussen, H.H. Horton, R.L. Newhall, D.E. Wilson, G.W. Kidd, and T.C. Roberts, Jr. White Rocks Road Immigrant forage kochia trial seedings. Rangelands 16:167-168. 